\title{
FAILURE UNDER STRESS OF GRAPEVINE WOOD: THE EFFECTS OF THE CERAMBYCID Xylotrechus arvicola ON THE BIOMECHANICS PROPERTIES OF Vitis vinifera
}

\author{
Álvaro Rodríguez-González ${ }^{1, \triangleleft}$, Pedro A. Casquero ${ }^{1}$, Guzman Carro-Huerga ${ }^{1}$, Julia García-González ${ }^{2}$, \\ Samuel Alvarez-García ${ }^{1}$, Andrés Juan-Valdés ${ }^{2}$
}

\begin{abstract}
Xylotrechus arvicola is an insect pest on Vitis vinifera in the main wine-producing regions of Spain. $X$. arvicola larvae bore inside grapevine wood, which cause structural damages in the plants' biomechanical properties. Grapevine wood affected and unaffected by larvae, were collected from vineyards. Compression and flexural tests were used to quantify biomechanical wood properties. Affected wood broke more quickly and endured a lower supported force than unaffected wood in both varieties and moisture states. Tempranillo was the most resistant variety on trunks, while Cabernet-Sauvignon was the most resistant variety on branches, where all infested varieties showed a lower rate of bending. Grapevine wood affected by $X$. arvicola larvae shows an important decrease in its resistance in both moisture states - dry and wet wood - and it is observed due to the faster break in time and a lower supported force. These damages give the affected wood greater sensitivity to external mechanical factors in the vineyards, such as strong winds, harvest weight and the vibration exerted by harvesting machines. The aspect of stress-time curves in all cases follow similar patterns, so in future studies might be possible to stablish relationships between both wet and dry samples and different infestation levels.
\end{abstract}

Keywords: Cerambycid, compressive test, flexural test, insect borer, vineyard.

\section{INTRODUCTION}

Xylotrechus arvicola (Coleoptera: Cerambycidae) is a xylophagous polyphagous insect native to riverside trees, being the genus Quercus spp., Carpinus spp., Castanea spp., Fagus spp., Populus spp., Salix spp., Tilia spp., Morus spp., Sorbus spp., Crataegus spp., Malus spp., Cydonia spp. and Prunus spp., the hosts reported (Bahillo 1996, Vives 2000, Moreno 2005, Biurrun et al. 2007). Its geographical distribution is mediterranean, spreading around Europe, Minor Asia and northern Africa (Villiers 1978, Nikitsky et al. 2016). This insect has become a pest of grapevines (Vitis vinifera) in the main wine-producing regions of the Iberian Peninsula (Ocete and del Tio 1996, Rodríguez and Ocaña 1997, Ocete and López 1999, Pelaez et al 2001, Ocete et al. 2002a). Trogoxylon impressum Comolli (Coleoptera: Lyctidae), Xyloperthodes incertus Lesne (Coleoptera: Bostrichidae) and Acalolepta vastator Newman (Coleoptera: Cerambycidae) are three species of wood borers that have been described as grapevine pests in Israel and wine-growing areas of Switzerland, Germany and Austria, South Africa and Australia, respectively (Goodwin and Pettit 1994, Halperin and Geis 1999, Allsopp and Knipe 2004).

Plant wood can be degraded by fungi and termites due to its biological origin (Syofuna et al. 2012). One of the most important causes of wood damage in plants are insects (Sen et al. 2017) that produce technical and economic losses (Ssemaganda et al. 2011). Sen et al. (2017) reported that the most important borer insects

\footnotetext{
${ }^{1}$ Grupo Universitario de Investigación en Ingeniería y Agricultura Sostenible (GUIIAS). Departamento de Ingeniería y Ciencias Agrarias. Instituto de Medio Ambiente, Recursos Naturales y Biodiversidad. Escuela de Ingeniería Agraria y Forestal. Universidad de León. León. España.

${ }^{2}$ Grupo de Investigación en Ingeniería de Materiales y Eco-Eficiencia (INMATECO). Departamento de Ingeniería y Ciencias Agrarias. Escuela de Ingeniería Agraria y Forestal. Universidad de León. León. España.

•Corresponding author: alrog@unileon.es
}

Received: 10.01.2019 Accepted: 14.12.2019 
are those belonging to the Cerambycidae, Anobidae and Lyctidae families. A wood-damaging insect type is Xylotrechus arvicola, which belongs to the Cerambycidae family from the Coleoptera class. This insect is most commonly observed in the main wine producing regions of the Iberian Peninsula, Spain, damaging wood of different varieties of vine (Vitis vinifera).

Adults of Xylotrechus arvicola measures between $8 \mathrm{~mm}$ and $20 \mathrm{~mm}$ in length. The average size of the female is larger than the male, their coloration is brown or blackish and the pronotal and elytral bands are usually yellow (Moreno et al. 2003). After mating, X. arvicola females lay eggs, concentrated in cracks or under the rhytidome in the vine wood (Pelaez et al. 2002). The fecundity and viability of eggs laid by X. arvicola females are extended over a long period of time (Rodríguez-González et al. 2016a). The location of the eggs enables the emerging larvae to move into the wood, making galleries inside the plant (Garcia-Ruiz 2009). The most susceptible states of the specie are adults, eggs and neonate larvae, although eggs are usually protected by the rhytidome or crack. The larvae, once inserted in the wood, are inaccessible when treated with traditional chemicals compounds (Pelaez et al. 2002) that do not have penetrative attributes (Rodríguez-González et al. 2017). Another problem is the treatment on $X$. arvicola adults, because it has an emergence pattern which is very staggered over time (Garcia-Ruiz 2009).

As was briefly commented in the previous paragraph, the damage to grapevines is caused by $X$. arvicola larvae which bore into grapevine plants to feed on wood making galleries within the plant for up to two years (Moreno 2005). Also, indirect damaged is caused by the formation of adult emerging holes which are the entry point for fungal diseases (Garcia-Benavides et al. 2013) such as Diplodia seriata (De Not), Eutypa lata (Tul and Tul), Phaeoacremonium minimum (Tul. and C. Tul), Phaeomoniella chlamydospora (Crous and Gams), and Formitiporia mediterranea (Fisch). Consequently, infection of fungal diseases on grapevines will cause a serious impact on host plants, e.g. stunting growth, low quality grape..., specifically on main grape varieties in Spain such as Tempranillo or Cabernet-Sauvignon (Ocete et al. 2002b, Garcia-Benavides et al. 2013). In severe attacks lasting years, plants die due to damaged plant vascular tissue, making it more difficult for sap to be transported along the plant, thus needing the plant to be replaced with the corresponding long lasting economic losses (Ocete et al. 2002a). A typical vineyard affected by $X$. arvicola will show numerous broken branches due to the larvae galleries weakening the wood structure of the plant (Garcia-Ruiz 2009). Cultural measures to control $X$. arvicola consist of removing the rhytidome of the grapevines (Pelaez et al. 2006) or pruning affected branches below the area of galleries (Ocete et al. 2004), to the grapevine structure to grow again, which could be time consuming and financially draining, as these techniques are expensive and not sustainable (Pelaez et al. 2006). The renovation of attacked branches in grapevines is easier with the bush vines training system than in grapevines with bilateral cordon training systems (Rodríguez-González et al. 2016b).

Other borers such as Spondylis buprestoides (Coleoptera: Cerambycidae) have been observed to cause damage in coniferous forests, especially in Scots pine, and other types of pine, spruce and fir in Australia, Siberia, Korea, Japan, and China (Kolk and Starzyk 1996). Moreover, the Esmerald Ash Borer (EAB) Agrilus planipennis Fairmaire (Coleoptera: Buprestidae) has become an important pest, which is decimating white ash populations in North America nowadays (Persad et al. 2013, Persad and Tobin 2015, Finley et al. 2016).

Returning to this insect pest (X. arvicola) in this crop ( $V$. vinifera), the grapevine wood structure resistance is of paramount importance owing to the many functions it performs. There is no information on grapevine wood material resistance once it has been affected by $X$. arvicola larvae. This is the argument for this study, in order to provide more information in how wood-borers' galleries affect structure and material properties of woody plants and all its implications. This information will be important for measuring how this pest could affect grapevine wood resistance. Consequently, having this information would enable vinicultors to estimate the wood resistance under those physical challengues present in vineyard (e.g. wind, grape carrying capacity, bunch carrying capacity, mechanical harvest). The present study would enable an estimate of the wood resistance loss in a vineyard affected by $X$. arvicola.

The aim of this study was to investigate the biomechanical properties of wood branches and trunks of grapevines, affected and unaffected by $X$. arvicola larvae, simulating the stresses (compression and flexural) to which they are subjected in the field. 


\section{MATERIAL AND METHODS}

\section{Vineyards of study}

Two vineyards where severe pruning was taking place to rebuild the plant structure and avoid $X$. arvicola spreading were sampled during 2017 and 2018. The vineyards were located in a Protected Denomination of Origin (PDO), which is a certification to distinguish quality food products of a particular region (UE Reg. No. 1151/2012 published on 21 November 2012), called 'Ribera Del Duero', located in Peñafiel (Valladolid; Spain). These vineyards were planted uniformly with the same $V$. vinifera variety ('Tempranillo' and 'Cabernet-Sauvignon'), planted in soils with Franco-Sandy texture, each variety being 26 and 29 years old, respectively). Vines were spaced $3 \mathrm{~m} \times 1,5 \mathrm{~m}$ and were surrounded by other vineyards. The training sytem of vines was 'Espaldera' (Double Cord or Royat), formed by two branches $(1,0 \mathrm{~m})$ and a trunk $(0,7 \mathrm{~m})$ in length.

\section{Wood samples and experimental conditions}

Wood trunks and branches from different grapevines, which were previously exposed to X. arvicola larvae attack a number of years, were collected to study the cumulative effects of larvae feeding in the vascular tissues of grapevine wood over time. Wood samples were randomly selected from affected and unaffected trunks and branches per grapevine and variety ('Tempranillo' and 'Cabernet-Sauvignon') in order to make a comparison between affected and unaffected woods within the same variety.

Grapevine wood varieties were labelled as affected and unaffected according to external observable symptoms described by Pelaez et al. (2006) (such as exit holes of adults and/or galleries in pruning cuts) and taken to laboratory. The European Standard EN 14251(2004) (Structural Round Timber, Test Methods) was used to calculate the necessary measures on wood samples before testing. The diameter and length of the sample trunks and branches were measured according to the European Standard cited. The wood samples that did not fulfil the requirements of the EN 14251(2004) standard were not considered for testing.

Part of the wood samples from both varieties were evaluated in fresh conditions (to avoid drying and to ensure that the moisture content was similar to that in the field). The rest of wood samples, to ensure the elimination of all moisture content, were air-dried for 30 days in laboratory ambient temperature $\left(26^{\circ} \pm 1^{\circ} \mathrm{C}\right)$ before mechanical testing. According to the European Standard EN 14251(2004) to calculate the moisture content of the wood samples, 10 specimens of each variety and part of the plant (trunks and branches with a diameter greater than $75 \mathrm{~mm}$ and without knots) were dried in the aforementioned laboratory conditions and were weighed at the beginning and end of the drying process. The following equation (Equation 1) was used to calculate the moisture percentage of the wet wood samples:

$$
M S=\frac{W S-D S}{D S} \times 100
$$

Where, MS (Moisture Samples) in percentage; WS (Wet Sample) in grams; DS (Dry Sample) in grams.

\section{Mechanical testing of wood samples}

The effects of $X$. arvicola larvae on the biomechanical properties of the plant in trunks and branches of $V$. vinifera varieties were evaluated using two standard experiments: a compression strength test for wood trunks and flexural strength test for wood branches.

All trunks and branches (wet and dry) were tested with a hydraulic press (i.e. a universal press of compression and bending) of the EIC (Engineering, Instrumentation and Control) brand of maximum load of $2000 \mathrm{kN}$. This apparatus applies the load by using a pump that generates oleohydraulic pressure and collects the data with a data logger. The EIC software takes the total applied load and voltage data. Performed data collection and processing was carried out with EIC software, in which the loading rate was the same for all the experiments, $200 \mathrm{~N} / \mathrm{s}$. The trunks were placed vertically to mimic the compression strength in the field, placing the surfaces of both ends which had been cut perpendicular to the longitudinal axis of the sample (Figure 1A). The branches were placed horizontally, trying to load branches topside in down position, to mimic downward 
bending in the field with a support span of $30 \mathrm{~cm}$ (at 18 times the branch nominal diameter to minimize shear stresses), and applied the central load (Figure 1B). Trunks and branches that twisted or slipped during the run were omitted from the analyses.

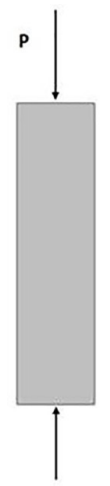

COMPRESSION (a)

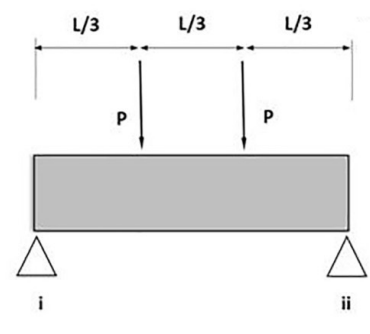

FLEXURAL

(b)

Figure 1: (a) Schemes of tests in trunks (P axial force applied until breakage). (b) Schemes of the test in branches (the forces $\mathrm{P}$ were applied in central third of the specimen until breakage, ' $\mathrm{i}$ ', and 'ii' were the supporting points in the extremes of wood samples).

\section{Experiment 1: Mechanical testing of grapevine wood trunks (break in time)}

In the compression test, different dimensions from each sample (wet and dry) were measured: 3 measurements of minimum diameter, 3 measurements of maximum diameter, and total sample length.

For the affected wood trunks samples, measurements of the number of adult exit holes and presence or absence of galleries appearing on both ends of the sample were also registered. The compressive test of samples was calculated according to the European Standard EN 14251(2004) and the following Equation 2, Equation 3, Equation 4, Equation 5, Equation 6:

$$
\begin{gathered}
\lambda=\frac{l k}{i} \\
i=\sqrt{\frac{I}{A}} \\
I=\frac{\pi r^{4}}{4} \\
A=\pi r^{2} \\
\sigma=\frac{N}{\pi r^{2}}
\end{gathered}
$$

Where, $\lambda:$ mechanical slenderness (dimensionless); $l k$ : buckling length or length of the test piece $(\mathrm{mm}) ; i$ : turning radius $(\mathrm{mm})$; I: moment of inertia $\left(\mathrm{mm}^{4}\right)$; A: transversal section area $\left(\mathrm{mm}^{2}\right) ; r$ : radius $(\mathrm{mm})$; $\sigma$ : normal 
tension $\left(\mathrm{MPa}=\mathrm{N} / \mathrm{mm}^{2}\right) ; \mathrm{N}$ : strength (Newtons).

In each mechanical testing, two break times were measured, time "T1", the time when the force applied by the hydraulic press to the wood sample remains constant, and time "T2", the time where the wood sample is completely broken.

\section{Experiment 2: Mechanical testing of grapevine wood branches (break in time)}

In the flexural test different dimensions from each sample (wet and dry) were measured: 3 measurements of minimum diameter, 3 measurements of maximum diameter, 2 measurements at the midpoint where the load is exerted (one in the direction of the load and another one in the perpendicular direction to the load) and total sample length.

For the affected wood branches, the number of adult exit holes and presence or absence of galleries appearing on both ends of the sample were also measured. The flexural test of samples was calculated according to the European Standard EN 14251(2004) and the following Equation 3, Equation 4, Equation 7, Equation 8:

$$
\begin{gathered}
A=\pi r^{2} \\
\sigma=\frac{M_{Z}}{W_{Z}}=\left(\frac{M_{Z}}{I}\right) r
\end{gathered}
$$

Where, I: moment of inertia $\left(\mathrm{mm}^{4}\right)$; A: transversal section area $\left(\mathrm{mm}^{2}\right) ; r$ : radio $(\mathrm{mm}) ; \sigma$ : normal tension (flexural) $\left(\mathrm{MPa}=\mathrm{N} / \mathrm{mm}^{2}\right) ; \mathrm{M}_{\mathrm{Z}}$ : bending moment $(\mathrm{N} \cdot \mathrm{mm}) ; \mathrm{W}_{\mathrm{Z}}$ : resistant module $\left(\mathrm{mm}^{3}\right)$.

In each mechanical testing, two break times were measured 'time $\mathrm{T} 1$ ', the time when the force applied by the hydraulic press to the wood sample remains constant, and 'time T2', the time where the wood sample is completely broken.

\section{Statistical analysis}

Statistical analyses were performed using the SAS software version 9.1.2 (SAS Institute Inc. 2004). Means parameters (supported force and time) evaluated on trunks and branches were performed using analysis of variance (Fisher's LSD, considered significant at $\mathrm{p} \leq 0,05$ ) to evaluate the biomechanics properties of affected and unaffected grapevine wood.

\section{RESULTS}

\section{Experiment 1: Mechanical testing of grapevine wood trunks (break in time)}

The moisture content obtained in wet trunks samples was $63,8 \%$ in Tempranillo and 57,0 \% in Cabernet-Sauvignon.

Concerning the time needed to break wet trunks, unaffected Tempranillo and Cabernet-Sauvignon showed the highest time of resistance under compression test, which was significantly greater than their respective affected samples in the two measurement times described (Figure 2A). Affected varieties presented an average of 2,0 holes $(5,6 \mathrm{~mm}$ in diameter) and 1,0 gallery $(10,6 \mathrm{~mm}$ in diameter) in Tempranillo and, an average of 3,0 holes $(5,3 \mathrm{~mm}$ in diameter) and 1,0 gallery (11,4 $\mathrm{mm}$ in diameter) in Cabernet-Sauvignon. After being dried, only Cabernet-Sauvignon (unaffected), showed a break in time (363,6 s in T1 and 472,0 s in T2) significantly greater than its respective affected samples in time T1 $(F=10,41$; d.f. $=3,16 ; P \leq 0,001)$ and T2 $(F=7,77$; d.f. $=3,16 ; P \leq 0,001)$ (Figure 2B). Affected Cabernet-Sauvignon presented an average of 1,3 holes $(4,7 \mathrm{~mm}$ in diameter) and an average of 7,7 galleries (4,6 $\mathrm{mm}$ in diameter).

Concerning the supported force in wet trunks, unaffected Tempranillo and Cabernet-Sauvignon varieties showed the highest resistance under compression test (8,2 $\mathrm{MPa}$ and 6,7 $\mathrm{MPa}$, in Tempranillo and Cabernet-Sauvignon respectively), significantly greater than their respective affected samples (Figure $2 \mathrm{~A}$ ). The 
behavior of the dry varieties was similar, in these conditions unaffected Tempranillo and Cabernet-Sauvignon showed the highest resistance under compressive test, 11,3 MPa in Tempranillo and 7,7 MPa in Cabernet-Sauvignon, significantly greater $(F=6,78$; d.f. $=3,16 ; P=0,004)$ than their respective affected samples (Figure $2 \mathrm{~B}$ ).

Wet Trunks
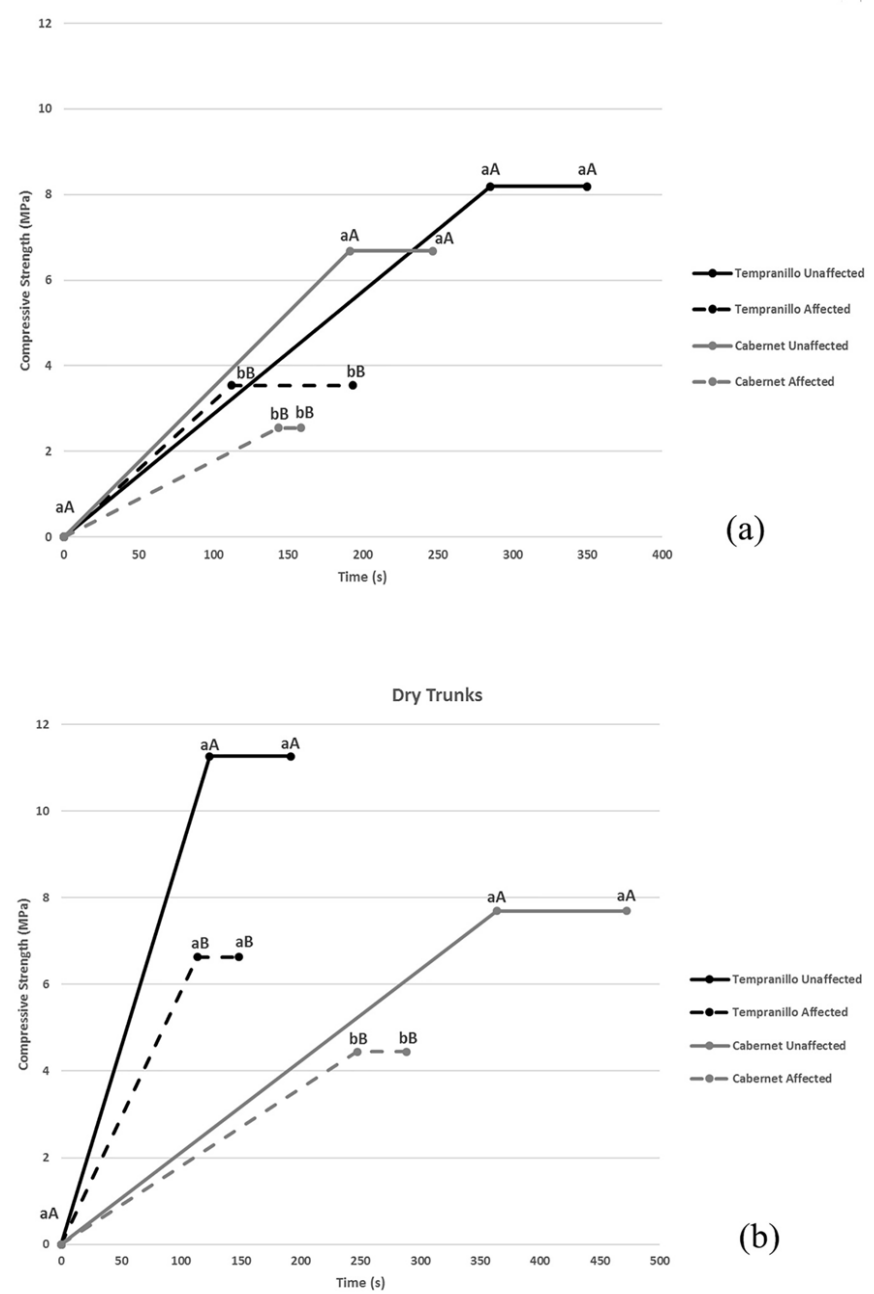

Figure 2: Diagram of compression test in grapevine trunks (a), wet wood; (b), dry wood), depicting the stress-time curve. All samples were loaded at the same rate, and load (represented as MPa, y-axis) as well as breakage in time (x-axis) were measured. 'Dashed line' represents wood samples infected by X. arvicola larvae, with higher stress and time at breakage; 'Continuous line' represents unaffected wood samples, with higher stress and time at breakage. Different lowercase letters indicate significant differences between grapevine trunks of each variety (affected and unaffected) in the same breakage in time. Different capital letters indicate significant differences between grapevine trunks of each variety (affected and unaffected) in the supported force.

\section{Experiment 2: Mechanical testing of grapevine wood branches (break in time)}

The moisture content obtained was $62,5 \%$ in Tempranillo and 59,6 \% in Cabernet-Sauvignon in samples of wet branches.

In relation to break in time of wet branches, Cabernet-Sauvignon and Tempranillo unaffected showed the highest time of resistance under flexural test, which was significantly greater than their respective affected samples in the time $\mathrm{T} 1(\mathrm{~F}=3,43$; d.f. $=3,16 ; \mathrm{P}=0,042)$ y $\mathrm{T} 2(\mathrm{~F}=5,98 ;$ d.f. $=3,16 ; \mathrm{P}=0,006)$ measured (Figure $3 \mathrm{~A})$. Affected varieties presented an average of 3,0 holes $(6,6 \mathrm{~mm}$ diameter $)$ and 3,7 galleries $(8,85 \mathrm{~mm}$ in diameter) 
in Cabernet-Sauvignon and, an average of 2,0 holes $(4,7 \mathrm{~mm}$ in diameter) and 1,7 galleries $(4,7 \mathrm{~mm}$ in diameter) in Tempranillo. After being dried, only Cabernet-Sauvignon (unaffected), showed a break in time (56,0 s in $\mathrm{T} 1$ and 73,5 $\mathrm{s}$ in T2) significantly greater than its respectively affected samples in both times measured (Figure 3B). Affected variety (Cabernet-Sauvignon) presented an average of 1,0 hole per sample (4,7 mm in diameter) and 2,0 galleries $(5,3 \mathrm{~mm}$ in diameter).

Regarding the supported force in wet branches, unaffected Cabernet-Sauvignon and Tempranillo, showed the highest resistance under flexural test $(75,3 \mathrm{MPa}$ and $66,4 \mathrm{MPa}$, in Cabernet-Sauvignon and Tempranillo respectively), significantly greater than their respectives affected samples (Figure 3A). In the same dried branches, only Cabernet-Sauvignon (unaffected), showed the highest resistance under flexural test, 57,8 MPa, significantly greater $(\mathrm{F}=8,71$; d.f. $=3,16 ; \mathrm{P} \leq 0,001)$ than its respectively affected samples (Figure $3 \mathrm{~B})$.

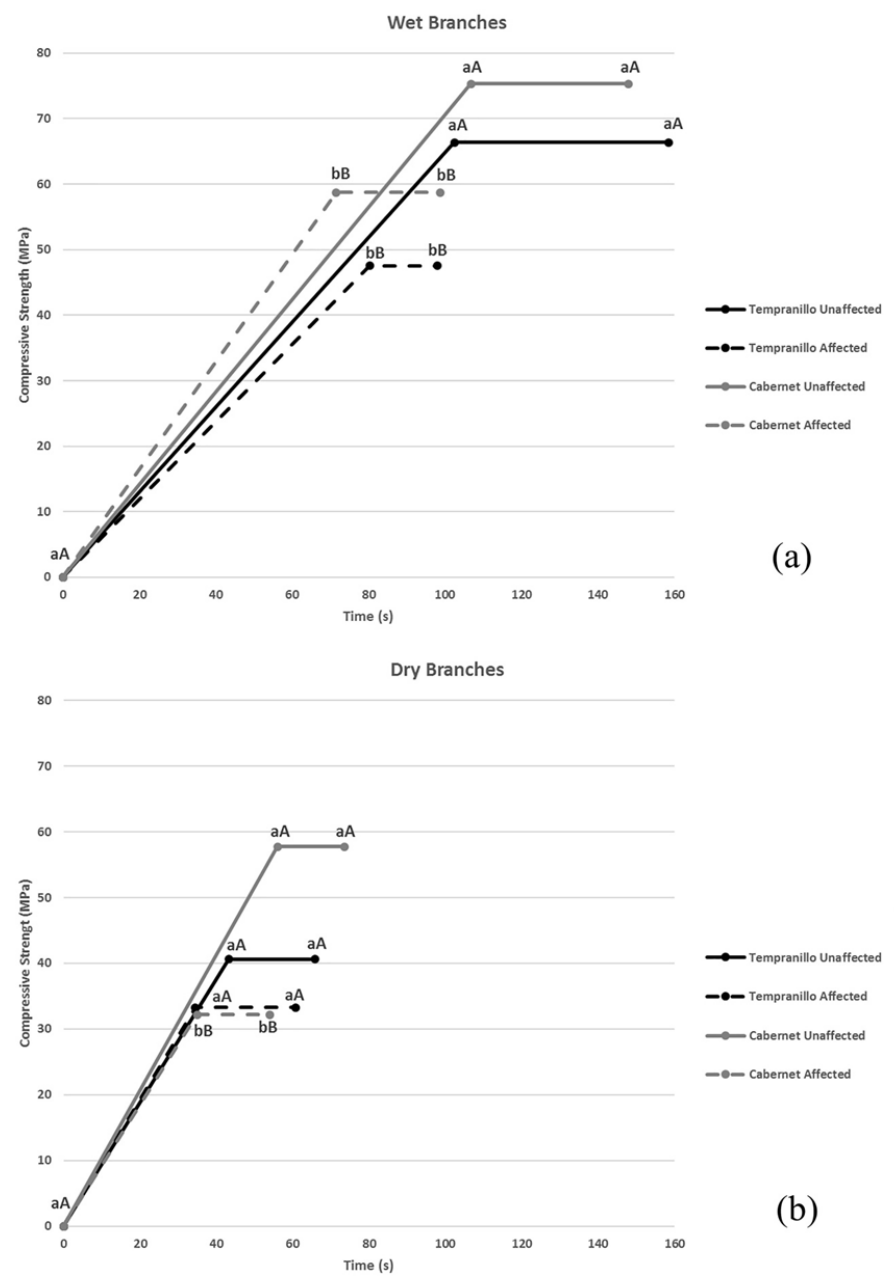

Figure 3: Diagram of flexural test in grapevine branches (a), wet wood; (b), dry wood), depicting the stress-time curve. All samples were loaded at the same rate, and load (represented as MPa, y-axis) as well as breakage in time (x-axis) were measured. 'Dashed line', represents wood samples infected by X. arvicola larvae, with higher stress and time at breakage; 'Continuous line' represents unaffected wood samples, with higher stress and time at breakage. Different lowercase letters indicate significant differences between grapevine branches of each variety (affected and unaffected) in the same breakage in time. Different capital letters indicate significant differences between grapevine branches of each variety (affected and unaffected) in the supported force. 


\section{DISCUSSION}

The tests carried out show $X$. arvicola larvae produce numerous damages on the biomechanics properties of $V$. vinifera wood in the varieties studied, such as a fast failure under stress or a decrease in its resistance (no matter whether the wood is wet or dry, or it is compressed or flexed).

Based on these results, damage caused by $X$. arvicola larvae can produce, in extreme situations, a break in vine branches affected (because the wood of the arms, both wet and dry, broke faster and withstood less force than their respective unaffected samples). This phenomenon has also occurred in other woody species such as hemlock woolly adelgid HWA Adelges tsugae Annand (Homoptera: Adelgidae) on Tsuga canadensis Carriére (Pinales: Pinaceae) (McClure 1991, Stadler et al. 2005). Also, Biurrun et al. (2007) have observed X. arvicola in Prunus pisardi Carrière, Koehne (Rosales: Rosaceae) trees causing the weakening of the affected trees and/ or the death or breakage of the affected branches for several years.

The lower supported force observed in the grapevine wood affected by X. arvicola larvae can be the indirect damage caused by the propagation of wood diseases that kill the vascular tissues of the wood and/or the direct damage caused by the reduction of vascular tissue of wood ingested by larvae.

Wood pathogens or diseases affect the biomechanical properties of other woody species, as it has been described in other genera, such as Pinus spp. (Kurkela et al. 2005, Drenkhan et al. 2006), Pseudotsuga spp. (Hansen et al. 2000) and Larix spp. (Krause and Raffa 1992). The action of X. arvicola larvae inside the grapevine wood favors the propagation of grapevine trunk diseases (described above in the introduction) through the emergence holes in the wood created by $X$. arvicola adults on their way out, leading to the death of plant vascular tissue (Ocete et al. 2002a, Garcia-Benavides et al. 2013). Tempranillo and Cabernet-Sauvignon varieties, which are two of the main varieties of Spanish vineyards, are the varieties where the fungal attack is more severe (Ocete et al. 2002a). Varieties affected by wood diseases accumulate a higher amount of dead wood that renders it to have a greater fragility, producing a gradual death of the affected areas, as also has been described by Hauer et al. (1993) in other woody species. James and Kane (2008) and Detters et al. (2008) have described that an accumulation of dead wood by the attack of pathogens on branches or trunks predisposes woody species affected to damage or breakage when they are subjected to external agents, such as snow, wind and static charges. Or static loads, such as weights of grapes (in harvest conditions) which grapevine wood is exposed at the time of production.

Ingestion of vascular tissue by insect larvae affects physical properties of wood species. X. arvicola larvae feeding modify the physical properties of trunks and branches of grapevine wood varieties, due to the decreased of break in time and supported force. The continuous years of infestation by these larvae in woody tissues pronounced changes in wood will be identified. Hence, leaf development becomes scarce and shoots are not very vigorous and productive (Moreno et al. 2004). Moreover, clusters are smaller, flowers are fewer and shorter in length, and they drop more easily (Ocete et al. 2002b). Soltis et al. (2014) described that branches breakage due to physical factors can reduce plant fitness because of biomass and meristem loss, showing the same results of biomechanics effects on Tsuga canadensis produced by Adelges tsugae. If woody species have suffered previous damage, several years of strong gusts of wind can cause mechanical instability (Spatz and Bruechert 2000).

Affected wood trunks and branches evaluated (wet and dry) supported a lower force and they broke more quickly, respect to uninfested wood. These wood varieties (trunks and branches) could become more sensitive to external mechanical factors, as is the case in other woody species (Soltis et al. 2014), such as the weight of the grape harvest, and/or vibration exerted by harvesting machines in those vineyards that use this technique. The aspect of the stress-time curves in all cases follow similar patterns, so in future studies it may be possible to stablish relationships between both wet and dry samples and different infestation levels.

\section{CONCLUSIONS}

This work shows the failure under stress (compression and flexural tests) of grapevine wood (trunks and branches) bored by $X$. arvicola larvae. Affected trunks broke more quickly, 112,0 s and 143,0 s in Tempranillo and Cabernet Sauvignon, respectively, and endured a lower force, not exceeding 6,6 MPa in both varieties and conditions of the wood, in the compression test. In addition, affected branches broke more quickly, 71,5 $\mathrm{s}$ and 34,5 s in Cabernet Sauvignon and Tempranillo, respectively, and endured a lower force, not exceeding 
$58,7 \mathrm{MPa}$ in both varieties and conditions of the wood, in the flexural test. Tempranillo was the most resistant variety on wood trunks and Cabernet-Sauvignon was the most resistant variety on wood branches, all infested varieties showing a lower bending moment. Attending to results, it cannot be ruled out that in an extreme situation, the damage caused by larvae can produce a break (by bending) in branches of grapevines over time. The infestation of grapevine wood trunks and branches by $X$. arvicola larvae produces numerous damages in biomechanics properties of vascular tissue and causes an important decrease in its resistance, in both moisture conditions (wet and dry), and it is observed through the speed of break in time and a lower supported force. These damages give the affected wood a greater sensitivity to external mechanical factors in the vineyards such as strong winds, harvest weight and the vibration exerted by harvesting machines. The aspect of the stresstime curves in all cases follow similar patterns, so in future studies it may be possible to stablish relationships between both wet and dry samples and different infestation levels.

\section{ACKNOWLEDGEMENTS}

The authors would like to thank to "Pago de Carraovejas" wine cellar for the project "Solución global para mejorar la producción vitivinícola frente al cambio climático basada en robótica, en tecnología IT y en estrategias biotecnológicas y del manejo del viñedo" (Acronym: GLOBALVITI; Reference: IDI-20160746).

\section{REFERENCES}

Allsopp, E.; Knipe, M. 2004. Wood borers in vines: A new pest or a climatic phenomenon?. Technical Yearbook 2004/5. Agricultural Research Council, Stellenbosch, South Africa. 85p.

Bahillo, P. 1996. Cerambícidos (Coleoptera, Cerambycidae) del País Vasco. Cuadernos de Investigación Biológica 19: 1-274. https://dialnet.unirioja.es/servlet/tesis?codigo=214435.

Biurrun, R.; Yanguas, R.; Garnica, I.; Benito, A. 2007. El taladro del endrino. Navarra Agraria 164: 47-51. https://www.navarraagraria.com/categories/item/612-xylotrechus-arvicola-el-taladro-del-endrino.

Detters, A.; Cowell, C.; Mckeown, L.; Howard, P. 2008. Evaluation of current rigging and dismantling practices used in arboriculture. Report submitted to the Health and Safety Executive and the Forestry Commission RR668. UK. 370p. https://www.hse.gov.uk/research/rrpdf/rr668.pdf.

Drenkhan, R.; Kurkela, T.; Hanso, M. 2006. The relationship between the needle age and the growth rate in Scots pine (Pinus sylvestris): a retrospective analysis by needle trace method (NTM). Eur J For Res 125(4): 397-405. https://doi.org/10.1007/s10342-006-0131-9.

Finley, K.; Chhin, S.; Nzokou, P. 2016. Effects of climate on the radial growth of white ash infested with emerald ash borer. Forest Ecol Manag 379: 133-145. https://doi.org/10.1016/j.foreco.2016.08.008.

Garcia-Benavides, P.; Martin-Zamorano, P.; Ocete-Pérez, C.; Maistrello, L.; Ocete, R. 2013. Biodiversity of pathogenic wood fungi isolated from Xylotrechus arvicola (Olivier) galleries in vine shoots. $J$ Int Sci Vigne Vin 47(2): 73-81. https://doi.org/10.20870/oeno-one.2013.47.2.1540.

Garcia-Ruiz, E. 2009. Contribución al Manejo de Plagas en vid: Xylotrechus arvicola Olivier (Coleoptera: Cerambycidae) y Lobesia botrana Denis \& Schiffermüller (Lepidoptera: Tortricidae). PhD Thesis, University of La Rioja, Logroño, Spain. https://dialnet.unirioja.es/servlet/tesis?codigo=20234.

Goodwin, S.; Pettit, M.A. 1994. Acalolepta vastator (Newman) (Coleoptera: Cerambycidae) Infesting Grapevines in the Hunter Valley, New South Wales 2. Biology and Ecology. Austral Entomol 33(4): 391-397. https://doi.org/10.1111/j.1440-6055.1994.tb01258.x.

Halperin, J.; Geis, K.U. 1999. Lyctidae (Coleoptera) of Israel, their damage and its prevention. Phytoparasitica 27(4): 257-262. https://doi.org/10.1007/BF02981481.

Hansen, E.M.; Stone, J.K.; Capitano. B.R.; Rosso, P.; Sutton, W.; Winton, L. 2000. Incidence and impact of Swiss needle cast in forest plantations of Douglas fir in coastal Oregon. Plant Dis 84(7): 773-778. 
DOI: https://doi.org/10.1094/PDIS.2000.84.7.773.

Hauer, R.; Wing, J.W.; Dawson, J.O. 1993. Ice storm damage to urban trees. Arboriculture J 19(4): 187193. https://www.hilltowntreeandgarden.com/pdf/ice-storm-damage-urban-trees.pdf.

James, K.; Kane, B. 2008. Precision digital instruments to measure dynamic wind loads on trees during storms. Agric For Meteorol 148(6-7): 1055-1061. https://doi.org/10.1016/j.agrformet.2008.02.003.

Kolk, A.; Starzyk, J.R. 1996. The Atlas of Forest Insect Pests. The Polish Forest Research Institute: Warsaw, Poland. 705p.

Kurkela, T.; Aalto, T.; Varama, M.; Jalkanen, R. 2005. Defoliation by the common pine sawfly (Diprion pini) and subsequent growth reduction in Scots pine: a retrospective approach. Silva Fenn 39(4): 467-480. https://jukuri.luke.fi/handle/10024/532593.

Krause, S.C.; Raffa, K.F. 1992. Comparison of insect, fungal, and mechanically induced defoliation of larch: effects on plant productivity and subsequent host susceptibility. Oecologia 90(3): 411-416. https://doi. org/10.1007/BF00317699.

Mcclure, M.S. 1991. Density-dependent feedback and population cycles in Adelges tsugae (Homoptera: Adelgidae) on Tsuga canadensis. Environ Entomol 20(1): 258-264. https://doi.org/10.1093/ee/20.1.258.

Moreno, C.M. 2005. Xylotrechus arvicola (Olivier, 1795) (Coleoptera: Cerambycidae): descripción morfológica, ciclo biológico, incidencia y daños en el cultivo de la vid. PhD Thesis, Instituto Tecnológico Agrario de Castilla y Léon (ITACYL). Valladolid, Spain. https://dialnet.unirioja.es/servlet/tesis?codigo=186183.

Moreno, C.M.; Martín, M.C.; Santiago, Y.; De Evan, E.; Hernández, J.M.; Pelaez, H. 2004. Presencia de Xylotrechus arvicola (Olivier, 1795) (Coleoptera:Cerambycidae) en viñedos de la zona centro de Castilla y León. Bol San Veg Plagas 30(3): 475-486. https://www.miteco.gob.es/ministerio/pags/biblioteca/plagas/ BSVP-30-03-475-486.pdf.

Moreno, C.M.; Martín, M.C.; Urbez. J.R.; Maraña, R.; Moro, S.; García, D.; Pelaez, H. 2003. Descripción de dos coleópteros que afectan al viñedo en Castilla y León. Phytoma 147: 34-42. https://dialnet. unirioja.es/servlet/articulo? codigo $=311988$.

Nikitsky, N.B.; Vlasenko, A.S.; Legalov, A.A. 2016. New records of beetles (Coleoptera) from Moscow region. Evraziatskii Entomologicheskii Zhurnal / Euroasian Entomol J 15(5): 416-419. http://kmkjournals. com/upload/PDF/EEJ/15/EEJ15_5_416_419.pdf.

Ocete, R.; Del Tío, R. 1996. Presencia del perforador Xylotrechus arvicola (Olivier) (Coleoptera: Cerambycidae) en viñedos de la Rioja Alta. Bol San Veg Plagas 22: 199-202. https://www.miteco.gob.es/ministerio/ pags/biblioteca/plagas/BSVP-22-01-199-202.pdf.

Ocete, R.; López, M.; Gallardo, A.; Pérez, M.; Rubio, I. 2004. Efecto de la infestación de Xylotrechus arvicola (Olivier) (Coleoptera: Cerambycidae) sobre la floración de la variedad Tempranillo en La Rioja. Bol San Veg Plagas 30(2): 311-316. https://www.miteco.gob.es/ministerio/pags/biblioteca/plagas/BSVP-30-02311-316.pdf.

Ocete, R.; López, M.; Prendes, C.; Lorenzo, C.; González-Andújar, J.; Lara, M. 2002a. Xylotrechus arvicola (Olivier) (Coleoptera, Cerambycidae), a new impacting pest on Spanish vineyards. Vitis 41(4): 211-212. https://ojs.openagrar.de/index.php/VITIS/article/view/4483/4416.

Ocete, R.; López, R. 1999. Principales insectos xilófagos de los viñedos de la Rioja Alta y Alavesa. Viticultura-Enología Profesional 62: 24-30. https://dialnet.unirioja.es/servlet/articulo?codigo=159158.

Ocete, R.; López-Martínez, M.; Prendes, C.; Lorenzo, C.; González-Andújar, J. 2002b. Relación entre la infestación de Xylotrechus arvicola (Coleoptera: Cerambycidae) (Olivier) y la presencia de hongos patógenos en un viñedo de la Denominación de Origen "La Mancha". Bol San Veg Plagas 28: 97-102. https:// www.mapa.gob.es/ministerio/pags/Biblioteca/Revistas/pdf_plagas\%2FBSVP-28-01-097-102.pdf.

Pelaez, H.; Moreno, C.; Santiago, Y.; Maraña, R.; Urbez, J.R.; Lambert, S.M.; María, C.M.; Evan, 
E.; Barrigón, J.; Prada, P.V. 2006. Xylotrechus arvicola: un cerambícido en el cultivo de la vid. Terralia 55: $50-60$.

Pelaez H.; Hernández, J.; Martín, M.; Moreno, C.; Santiago, Y. 2002. Determinación de las características del huevo de Xylotrechus arvicola (Coleoptera: Cerambycidae, Olivier, 1795). In X Congreso Ibérico de Entomología (pp. 52). Libro de Actas del X Congreso Ibérico de Entomología. Zamora, Spain.

Pelaez, H.; Maraña, J.; Urbez, J.; Barrigón, J. 2001. Xylotrechus arvicola (Olivier, 1795) (Coleoptera: Cerambycidae). Presencia en los viñedos de Castilla y León. Actas de Horticultura 30(4): 475-486.

Persad, A.B.; Siefer, J.; Montan, R.; Kirby, S.; Rocha, O.J.; Redding, M.E.; Ranger, C.M.; Jones, A.W. 2013. Effects of emerald ash borer infestation on the structure and material properties of ash trees. Arboric Urban For 39(1): 11-16. https://naldc.nal.usda.gov/download/56360/PDF.

Persad, A.B.; Tobin, P.C. 2015. Evaluation of ash tree symptoms associated with emerald ash borer infestation in urban forests. Arboric Urban For 41(2): 103-109. http://joa.isa-arbor.com/request.asp? Journa$1 \mathrm{ID}=1 \&$ ArticleID $=3356 \&$ Type $=2$.

Rodríguez-González, A.; Pelaez, H.J.; González-López, O.; Mayo, S.; Casquero, P.A. 2016a. Reproductive patterns of Xylotrechus arvicola (Coleoptera: Cerambycidae), an emerging pest of grape-vines, under laboratory conditions. J Econ Entomol 109(3): 1226-1230. https://doi.org/10.1093/jee/tow045.

Rodríguez-González, A.; Pelaez, H.J.; Mayo, S.; González-López, O.; Casquero, P.A. 2016b. Biometric traits of Xylotrechus arvicola adults from laboratory and grape field. Vitis 55(2): 73-78. https://doi. org/10.5073/vitis.2016.55.73-78.

Rodríguez-González, A.; Mayo, S.; González-López, O.; Reinoso, B.; Gutiérrez, S.; Casquero, P.A. 2017. Inhibitory activity of Beauveria bassiana and Trichoderma spp. on the insect pests Xylotrechus arvicola (Coleoptera: Cerambycidae) and Acanthoscelides obtectus (Coleoptera: Chrisomelidae: Bruchinae). Environ Monit Assess 189: 12. https://doi.org/10.1007/s10661-016-5719-z.

Rodríguez, M.; Ocaña, P. 1997. Presencia del perforador Xylotrechus arvicola (Olivier) en viñas de la provincia de Ciudad Real-1996. XXII Reunión del Grupo de Trabajo de los Problemas Fitosanitarios de la Vid. Ciudad Real, Spain.

SAS. 2004. SAS version 9.1.2. SAS Institute Inc. Cary, NC, USA.

Sen, S.; Yalçin, M.; Tasçioglu, C.; Özbayram, A.K. 2017. Larvicidal activities of some bark and wood extracts against wood-damaging insects. Maderas- Cienc Tecnol 19(3): 273-284. http://dx.doi.org/10.4067/ S0718-221X2017005000023.

Soltis, N.E.; Gomez, S.; Leisk, G.G.; Sherwood, P.; Preisser, E.L.; Bonello, P.; Orians, C.M. 2014. Failure under stress: the effect of the exotic herbivore Adelges tsugae on biomechanics of Tsuga canadensis. Annals Bot-London 113(4): 721-730. https://doi.org/10.1093/aob/mct286.

Spatz, H.C.; Bruechert, F. 2000. Basic biomechanics of self-supporting plants: wind loads and gravitational loads on a Norway spruce tree. Forest Ecol Manag 135(1-3): 33-44. https://doi.org/10.1016/S03781127(00)00296-6.

Ssemaganda, I.E.; Mugabi, P.; Tumwebaze, S.B. 2011. Effectiveness of selected preservatives in protecting ugandan grown Eucalyptus grandis wood against termite attack. Maderas-Cienc Tecnol 13(2): 135142. http://dx.doi.org/10.4067/S0718-221X2011000200001.

Stadler, B.; Muller, T.; Orwig, D.; Cobb, R. 2005. Hemlock woolly adelgid in New England forests: canopy impacts transforming ecosystem processes and landscapes. Ecosystems 8(3): 233-247. https://doi. org/10.1007/s10021-003-0092-5.

Syofuna, A.; Banana, A.; Nakabonge, G. 2012. Efficiency of natural wood extractives as wood preservatives against termite attack. Maderas-Cienc Tecnol 14(2): 155-163. http://dx.doi.org/10.4067/S0718$221 X 2012000200003$. 
UNE-EN. 2004. Structural round timber - Test methods. UNE-EN 14251. 2004. AENOR: Madrid, Spain.

Villiers, A. 1978. Faune des Coléoptères de France. I Cerambycidae. Encyclopédie Entomologique XLII. 611 p. Lechevalier, Paris, France.

Vives, E. 2000. Coleoptera: Cerambycidae. In Fauna Ibérica (Vol. 12). Consejo Superior de Investigaciones Científicas CSIC: Madrid, Spain. 726p. 